\title{
Effect of linseed feeding on blood metabolites, incidence of cystic follicles, and productive and reproductive performance in fresh Holstein dairy cows
}

\author{
M. Jahani-Moghadam, ${ }^{*} E$. Mahjoubi, $\dagger^{1}$ and E. Dirandeh* \\ *Department of Animal Science, Sari Agricultural Sciences and Natural Resources University, Sari, Iran \\ †Department of Animal Science, University of Zanjan, Zanjan, Iran
}

\begin{abstract}
This study was done to investigate the effect of feeding linseed on blood metabolites, incidence of cystic follicles, resumption of postpartum ovarian cyclicity, pregnancy rate, milk production, and composition in fresh Holstein dairy cows. A total of 399 dairy cows were assigned randomly to 2 diets. Diets contained either protected palm oil (CON) or extruded linseed (LIN) and were fed from calving to d 40 postpartum. Ovaries of each cow were examined on d 10, 20, 30, and 40 after parturition (parturition $=\mathrm{d} 0$ ) by transrectal ultrasonography to determine follicular development, ovarian disorders, and cyclicity. Blood samples were collected at 14-d intervals for 6 wk starting on the day of parturition to determine plasma concentrations of glucose, $\beta$-hydroxybutyrate (BHBA), nonesterified fatty acids (NEFA), and blood urea N (BUN). Results showed plasma glucose concentration was affected by the diets and was greater in the LIN treatment, but BHBA, NEFA, and BUN concentrations were similar among treatments. Dietary treatments had no significant effect on milk production and composition except milk fat percentage that significantly decreased in cows fed LIN (3.55\%) compared with those fed with CON $(4.17 \%)$. Plasma progesterone concentrations were greater in LIN treatment than CON treatment (1.31 \pm 0.09 vs. $0.87 \pm 0.09)$ at early postpartum. The resumption of cyclicity and onset of estrus were influenced by treatments and reduced by $7 \mathrm{~d}$ in LIN treatment compared with CON treatment. Cows fed diets enriched in LIN fatty acids had a lesser incidence of cystic follicles. Treatments did not differ significantly in terms of the number of days open, number of services per pregnancy, and pregnancy rate. In conclusion, feeding linseed immediately after parturition decreased milk fat and incidence of cystic follicles, increased progesterone concentrations early postpartum, and caused earlier resumption of cyclicity but did not affect pregnancy rate.
\end{abstract}

\footnotetext{
Received August 26, 2014.

Accepted November 10, 2014.

${ }^{1}$ Corresponding author: e_mahjoubi@znu.ac.ir or e_mahjoubi133@ yahoo.com
}

Key words: fertility, Holstein dairy cow, linseed, postpartum, reproduction

\section{INTRODUCTION}

Negative energy balance in dairy cows after calving is characterized by low blood concentrations of glucose, insulin, and IGF-1 and high blood concentrations of NEFA and BHBA (Ingvartsen and Andersen, 2000). These shifts in blood metabolites and hormones might compromise ovarian function and fertility. Feeding diets that promote increases in plasma glucose and insulin may improve the metabolic and endocrine status of cows in early lactation (Santos et al., 2004).

In recent years, dietary fats rich in n-3 PUFA have been widely used to enhance reproductive performance in dairy cows (Silvestre et al., 2011; Caldari-Torres et al., 2011; Dirandeh et al., 2013a; Badiei et al., 2014) by improving dietary energy density (Ferguson et al., 1990); influencing follicular growth and ovulation (Silvestre et al., 2011; Dirandeh et al., 2013b); increasing the number, diameter, and the life span of the corpus luteum (CL; Garcia-Bojalil et al., 1998); increasing concentrations of progesterone (Santos et al., 2008; Dirandeh et al., 2013b); early postpartum ovarian cyclicity (de Veth et al., 2009); prevention of luteolytic signals around maternal recognition of pregnancy (Mattos et al., 2000; Dirandeh et al., 2013a); and improved embryo quality (Cerri et al., 2004).

Linseed and its oil have been used widely as a conventional source of n-3 PUFA that contain $>500 \mathrm{~g}$ of $\alpha$ linolenic acid (ALA) per kilogram of total fatty acid (Moallem, 2009). Linseed is incorporated into dairy feeds to improve reproduction and milk quality in dairy cows (Dirandeh et al., 2013b). Feeding protected linseed or its protected oil may enhance reproductive performance and increase the n-3 PUFA content of milk fat (Gonthier et al. 2005). Recent studies have shown a $16 \%$ increase in pregnancy rate in cows fed linseed compared with those fed palm oil (Dirandeh et al., 2013a).

Because ovarian activity usually returns within the first $4 \mathrm{wk}$ of calving, initiating fat feeding prepartum would allow the absorbed fatty acids to influence early 
ovarian activity (Santos et al., 2010). The incidence of cystic follicles is higher in high-producing dairy cows and is associated with lower percentages of pregnancy per AI and increases interval to pregnancy, culling, and economic losses. Cows with cystic follicles take 6 to $11 \mathrm{~d}$ longer to first service and 20 to 30 more days to conception (Fourichon et al., 2000).

Although many experiments have determined the effects of n-3 PUFA supplementation on productive and reproductive performances, little information is available on the effects of feeding linseed immediately postpartum on parameters influencing reproduction such as the incidence of cystic follicles and resumption of postpartum ovarian cyclicity. Therefore, the objectives of the current study were to determine the effect of linseed on blood metabolites, plasma concentrations of progesterone, resumption of postpartum ovarian cyclicity, incidence of cystic follicles, milk production, and composition and pregnancy rate in fresh Holstein dairy cows.

\section{MATERIALS AND METHODS}

\section{Cows and Treatments}

The experiment was conducted on a commercial dairy farm in Iran from November 2011 to April 2012 using 399 Holstein dairy cows (yielding $30.4 \pm 0.3 \mathrm{~kg}$ of milk/d, 199 primiparous and 200 multiparous) with no overt clinical illnesses. The experiment was conducted from calving until wk 6 of lactation. Cows were blocked according to calving date, parity, and BCS and randomly assigned to 1 of 2 isonitrogenous and isoenergetic total mixed diets (Table 1). No difference was present among groups (mean \pm SEM) in parity $(2.5 \pm$ 1.4) or BCS at calving $(3.2 \pm 0.07)$. All cows calved within 3 wk. Treatments included (1) protected palm oil (CON; Magnapac, Norel S.A., Suez, Egypt) and (2) extruded linseed (LIN, OmegaLin; Nutri Advance, Ploufragan, France). Diets were fed twice daily (0700 and $1700 \mathrm{~h}$ ) for ad libitum intake (10\% of refusals on an as-fed basis) during the whole experiment. Cows were milked 3 times daily at 0600, 1400, and $2200 \mathrm{~h}$. All cows had a similar dry period condition and were fed a diet primarily consisted of alfalfa, corn silage, barley grain, and wheat bran in far-off. The composition of close-up diet has been shown in Table 1. Mature cows and heifers were housed together during close-up and postfresh periods. Twenty-three days before the expected calving date, mature cows and heifers were moved to the closeup group in a twice per week schedule.

\section{Analysis of Feed}

Total mixed ration were sampled each week and pooled each month and analyzed. Briefly, the DM of the feed sample was determined by placing it in a drying oven at $100^{\circ} \mathrm{C}$ for $48 \mathrm{~h}$ (AOAC, 1990; method 930.15). Crude protein was determined using the $\mathrm{Du}$ mas method and a Leco FP-528 (Leco Corporation, St. Joseph, MI). Acid detergent fiber and NDF concentrations were determined (Van Soest et al., 1991).

\section{Milk Sampling and Analysis}

Milk production was recorded at every milking. Milk samples were taken weekly (Sunday and Tuesday; 3 times per day, milk samples pooled on a yield basis so only 1 sample was taken per week) during experiment and analyzed for fat, protein, and lactose by infrared spectroscopy (AOAC International, 2000; method 972.16). The Milkoscan 4000 uses infrared technology to analyze the components of milk.

\section{Blood Sampling and Processing}

Blood samples (only for 30 cows within each treatment, a total of 60 cows) were collected at 14-d intervals for 6 wk starting $24 \mathrm{~h}$ after parturition $(\mathrm{d}=$ 0 ) for determining glucose, BHBA, NEFA, and BUN. Blood samples (only for 20 cows per treatment, a total of 40 cows) were collected daily from d 10 to 25 postpartum for determination of plasma progesterone concentrations. Blood samples $(10 \mathrm{~mL})$ were collected, by coccygeal venipuncture into anticoagulated (EDTA) evacuated tubes (Monoject, Sherwood Medical, St. Louis, MO), before the feeding and were kept on ice. All blood samples were centrifuged for $10 \mathrm{~min}$ at 2,000 $\times g$ at $4^{\circ} \mathrm{C}$, and plasma was harvested and transferred into 2 - $\mathrm{mL}$ microcentrifuge tubes and kept at $-20^{\circ} \mathrm{C}$ until assayed. Plasma concentrations of glucose (Glucotrend, Roche, UK), NEFA (FA 115, Randox Laboratories Ltd., Antrim, UK), and BHBA (Abbott Diabetes Care Ltd., Witney, UK) were determined enzymatically using a spectrophotometer (Shimadzu 2100, Kyoto, Japan). Intra- and interassay coefficients of variation were $<5 \%$. Plasma progesterone concentrations were analyzed by ELISA following the manufacturer's instructions (DRG, Frauenbergstr, Marburg, Germany).

\section{Ultrasonographic Examination and Estrus Detection}

Cows were synchronized with $2 \mathrm{PGF}_{2 \alpha}$ injections $14 \mathrm{~d}$ apart started at d 45 postpartum. The voluntary waiting period of the dairy herd was $60 \mathrm{~d}$, and cows were inseminated based on a voluntary waiting period. Pregnancy diagnosis was performed by ultrasonography at d 32 after AI. Cows diagnosed pregnant at d 32 were reexamined at d $60 \pm 5$ after AI to confirm pregnancy (Dirandeh et al., 2014). 
Table 1. Ingredient and chemical composition of experimental diets and diet of postexperiment period

\begin{tabular}{|c|c|c|c|c|}
\hline Item & Close-up & $\mathrm{CON}$ & LIN & After 40 DIM \\
\hline \multicolumn{5}{|c|}{ Ingredient composition, $\%$ of DM } \\
\hline Alfalfa hay & 20.4 & 22.5 & 22.5 & 22.2 \\
\hline Corn silage & 37.6 & 16.2 & 16.2 & 18.5 \\
\hline Beet pulp & & 6.3 & 6.3 & 0 \\
\hline Ground barley grain & 12.7 & 11.2 & 11.2 & 17.4 \\
\hline Ground corn grain & 9.0 & 14.0 & 14.0 & 13.4 \\
\hline Wheat bran & 5.4 & 0 & 0 & 0 \\
\hline Cottonseed whole & 2.1 & 8.4 & 8.4 & 8.8 \\
\hline Canola meal & 6.0 & 0 & 0 & 0 \\
\hline Soybean meal $44 \%$ CP & 3.3 & 12.1 & 9.2 & 12.2 \\
\hline Corn gluten meal & 0.5 & 2.5 & 2.5 & 2.0 \\
\hline Linseed $(\text { OmegaLin })^{1}$ & 0 & 0 & 4.5 & 0 \\
\hline Magnapac $^{2}$ & 0 & 1.6 & 0 & 1.7 \\
\hline Mineral-vitamin $\operatorname{mix}^{3}$ & 0.8 & 0.6 & 0.6 & 0.4 \\
\hline Anionic salt & 1.1 & 0 & 0 & 0 \\
\hline Dicalcium phosphate & 0 & 0.2 & 0.2 & 0.2 \\
\hline Salt & 0 & 0.2 & 0.2 & 0.2 \\
\hline Sodium bicarbonate & 0 & 1.1 & 1.1 & 2.0 \\
\hline Calcium carbonate & 0 & 0.5 & 0.5 & 0.2 \\
\hline Bentonite & 0 & 0.7 & 0.7 & 0.8 \\
\hline Glycolaine $^{4}$ & 1.1 & 1.9 & 1.9 & 0 \\
\hline \multicolumn{5}{|c|}{ Chemical composition (DM basis) } \\
\hline $\mathrm{NE}_{\mathrm{L}},{ }^{5} \mathrm{Mcal} / \mathrm{kg}$ & 1.50 & 1.68 & 1.67 & 1.66 \\
\hline $\mathrm{CP}, \%$ & 13.4 & 16.8 & 16.4 & 16.8 \\
\hline NDF, \% & 40.0 & 30.3 & 31.1 & 30.7 \\
\hline Forage NDF, $\%$ & 31.1 & 18.4 & 18.6 & 19.6 \\
\hline $\mathrm{ADF}, \%$ & 25.3 & 20.1 & 20.5 & 20.2 \\
\hline $\mathrm{NFC}^{4} \%$ & 37.9 & 38.7 & 38.5 & 40.9 \\
\hline Ether extract, \% & 3.0 & 5.0 & 5.1 & 5.25 \\
\hline $\mathrm{RDP}^{4} \%$ & 10 & 11.5 & 11.0 & 11.7 \\
\hline $\mathrm{RUP}^{4} \%$ & 3.4 & 5.3 & 5.4 & 5.1 \\
\hline
\end{tabular}

${ }^{1}$ Omegalin consisted of $100 \mathrm{~g} / \mathrm{kg}$ of DM wheat meal and $900 \mathrm{~g} / \mathrm{kg}$ of DM extruded Tradi-Lin grain (Valorex, Combourtille, France). Tradi-Lin uses a patented process characterized by a preliminary maturing step of specific duration $(10-30 \mathrm{~min})$ and temperature $\left(<100^{\circ} \mathrm{C}\right)$, level of steam incorporation, and the mounting of the extruders (patent no. EP 1021960 B1).

${ }^{2}$ Calcium salts of fatty acids distillate from palm oil (Magnapac, NOREL S.A., Suez, Egypt). Analysis: $84 \%$. Fatty acid composition (NOREL S.A., g/kg of total fatty acids): C14:0, 1.5\% ; C16:0, 44\%; C18:0, 5\%; C18:1, 40\%; C18:2, 9.5\%.

${ }^{3}$ Provided (per $\mathrm{kg}$ of DM): 500,000 IU of vitamin A, 100,000 IU of vitamin D, 1,000 $\mathrm{mg}$ of vitamin E, 9,000 $\mathrm{mg}$ of P, 195,000 mg of Ca, 2,000 mg of Mn, 55,000 mg of Na, 2,000 mg of Zn, 2,000 mg of Fe, $280 \mathrm{mg}$ of Cu, 100 $\mathrm{mg}$ of $\mathrm{Co}, 100 \mathrm{mg}$ of $\mathrm{Br}, 1 \mathrm{mg}$ of Se, and 3,000 $\mathrm{mg}$ of antioxidant.

${ }^{4}$ DSL Chemical (Shanghai) Co. Ltd., Shanghai, China.

${ }^{5}$ Calculated using the NRC (2001) values.

Ovarian follicles were monitored from d 10 postpartum until detecting the first postpartum ovulation $(30 \pm 3.8)$ every other day to determine diameter of ovulatory follicle by transrectal ultrasonography using a real-time linear scanning ultrasound diagnostic system fitted to a Falco 100 B-mode scanner (ECM AL, Agroscan, Angoulême, France) as previously described by Dirandeh et al. (2009). The horizontal and vertical diameters of follicle were recorded and the average was used in the analysis; to determine ovarian disorders and cyclicity, ovaries of each cow were examined on d 10, 20, 30, and 40 after parturition (parturition $=\mathrm{d} 0$ ).

The cows were observed visually around the estrus period for estrus detection twice daily at approximately 12-h intervals for a minimum of $30 \mathrm{~min}$ per period. Ovulation was confirmed by the absence of a large (diameter $\geq 10 \mathrm{~mm}$ ) follicle that had been detected at the previous examination, and subsequent CL formation (Dirandeh, 2014). Anovulatory follicles $\geq 25 \mathrm{~mm}$ in diameter that persisted for at least $10 \mathrm{~d}$ in the absence of a CL were defined as cysts (Garverick, 1997).

\section{Statistical Analysis}

Data were tested for normal distribution of the residuals by the PROC UNIVARIATE procedure of SAS (v.8.0, SAS Institute, Cary, NC). Data on milk yield and composition, plasma concentrations of progesterone, and metabolites were analyzed as repeated measurements using PROC MIXED of SAS with the following model: 


$$
\begin{aligned}
\mathrm{Y}_{\mathrm{ijk}}=\mu & +\alpha_{\mathrm{i}}+\beta_{\mathrm{j}}+\tau_{\mathrm{k}}+(\alpha \beta)_{\mathrm{ij}}+(\alpha \tau)_{\mathrm{ik}} \\
& +(\beta \tau)_{\mathrm{jk}}+(\alpha \beta \tau)_{\mathrm{ijk}}+\mathrm{e}_{\mathrm{ijk}},
\end{aligned}
$$

where $\mu$ is the population mean; $\alpha_{i}$ is the treatment effect; $\beta_{\mathrm{j}}$ is the fixed effect of parity; $\tau_{\mathrm{k}}$ is the effect of sampling day or time; $(\alpha \beta)_{\mathrm{ij}}$ is the interaction effect of treatment and parity; $(\alpha \tau)_{\mathrm{ik}}$ is the interaction effect of treatment and sampling day or time; $(\beta \tau)_{\mathrm{jk}}$ is the interaction effects of parity and sampling day or time; $(\alpha \beta \tau)_{\mathrm{ijk}}$ is the interaction effects of treatment, parity, and sampling day or time; and $\mathrm{e}_{\mathrm{ijk}}$ is the residual error. Significance was declared at $P<0.05$.

Interval between calving and first artificial insemination and the number of days open were analyzed by survival analysis using the product limit method of the Kaplan-Meier model by the LIFETEST procedure of SAS. Significance and tendencies were declared at $P<0.05$ and $P<0.10$, respectively, unless otherwise indicated.

\section{RESULTS AND DISCUSSION}

\section{Milk Production and Composition}

Average DMI were 20.3 and $20.4 \mathrm{~kg} / \mathrm{d}$ for the CON and LIN groups, respectively. No increase in the overall milk yield was observed during the entire period of linseed feeding $(P=0.37$, Table 1$)$. Milk yield increased from calving until wk 6 postpartum in both groups $(P<0.05$, Table 1$)$. Results on the effect of linseed supplementation on milk yield have been controversial. Some studies have reported similar milk yields for cows supplemented or not with LIN (Gonthier et al., 2005; Dirandeh et al., 2013a) and others have shown an increase in milk yield when cows were fed LIN (Petit, 2002; Zachut et al., 2010). Zachut et al. (2010) reported milk yield until 100 DIM was $6.4 \%$ greater in the cows fed extruded linseed than in the control cows.

The lower milk fat proportion for cows fed LIN compared with those fed CON that reported in present study $(P=0.02$, Table 2$)$ was consistent with previous studies (Chilliard et al., 2009; Zachut et al., 2010; Dirandeh et al., 2013a) and might be the result of the higher intake of PUFA by LIN-fed cows. According to Bauman and Griinari (2001), biohydrogenation of PUFA by rumen microbes leads to milk fat depression and linseed contains around $500 \mathrm{~g} / \mathrm{kg}$ of total FA as linolenic acid (Fuentes et al., 2008). The first rumen biohydrogenation intermediate shown to affect milk fat synthesis is trans-10,cis-12 CLA (Baumgard et al., 2000). de Veth et al. (2004) reported a curvilinear relationship between increasing trans-10, cis-12 CLA dose and the reduction in milk fat yield. Chilliard et al. (2000) showed interest in the role of trans isomers of 18:1 in mediating the milk fat depression associated with certain dairy diets. Long-chain n-3 PUFA present in linseed appear to affect rumen bacteria that catalyze the terminal step in rumen biohydrogenation and cause a trans-10 FA to be produced (Griinari et al., 1998). Yields of fat and fat-corrected milk were not affected by treatment $(P=$ 0.22 , Table 2). Lower milk fat proportion also may be the result of the linseed product that was fed, which was the extruded form. Indeed, extruded linseed fed at $14.8 \%$ of the diet decreased fat concentration from 4.11 to $3.53 \%$ in late-lactating dairy cows compared with those fed a control diet (Martin et al., 2008). Decreased milk fat percentage was also observed by Chilliard et al. (2009) in cows fed a supplement containing $70 \%$ extruded linseed at $21.2 \%$ of the diet DM. Dirandeh et al. (2013a) reported milk fat concentration declined from 3.84 to $3.50 \%$ from wk 0 to 8 in cows fed linseed. Hutchinson et al. (2012) reported that CLA decreased milk fat percentage.

Milk protein percentage and yield did not differ between the dietary groups in our study $(P=0.47$, Table $2)$. No difference was found in lactose in the milk $(P$ $=0.64$, Table 2). The lack of a linseed effect on milk protein concentration in the present study probably was related to the low inclusion rate of linseed ( $45 \mathrm{~g} /$ $\mathrm{kg}$ of DM). Reports in the literature about the effects of linseed supplementation on the concentration of milk protein are inconsistent. Some studies have reported an increase in protein concentration (Petit, 2002; Fuentes et al., 2008), no effect (Petit and Benchaar, 2007), or a decrease (Ward et al., 2002). Schingoethe (1996) reviewed the effect of diet on protein concentration in the milk of dairy cows and concluded that it is easier to increase protein yield than concentration. Supplemental fat that increases milk yield will usually increase milk protein yield but reduce protein concentration (CSIRO, 2007), probably due to a dilution effect.

\section{Blood Metabolites and Progesterone Concentrations}

No significant differences were found among treatments for average plasma concentrations of metabolites $(P>0.05$, Table 2$)$ that were consistent with previous studies (Dirandeh et al., 2013a; Badiei et al., 2014). However, plasma glucose concentrations $(P=0.01)$ were higher in the LIN treatment compared with the CON treatment (Table 2). Dietary treatments had no effect on plasma concentrations of NEFA $(P=0.75)$ and BHBA $(P=0.62)$. No difference was observed among treatments from calving until wk 6 postpartum $(P>0.05$, Table 1). Blood concentration of NEFA is an index of body fat mobilization (Roberts et al., 1981) and is related to the energy balance of dairy cows. Bertics et al. (1992) reported that DMI is inversely related 
Table 2. Milk production and composition and blood metabolites of Holstein dairy cows fed diets based on protected palm oil (CON) or extruded linseed (LIN) from calving until wk 6 postpartum

\begin{tabular}{|c|c|c|c|c|c|c|}
\hline \multirow[b]{2}{*}{ Item } & \multicolumn{2}{|c|}{ Treatment } & \multirow[b]{2}{*}{ SEM } & \multicolumn{3}{|c|}{$P$-value } \\
\hline & $\mathrm{CON}$ & LIN & & Treatment & Time & Treatment $\times$ time \\
\hline $3.5 \% \mathrm{FCM}, \mathrm{kg} / \mathrm{d}$ & 42.9 & 40.4 & 2.6 & 0.54 & 0.01 & 0.37 \\
\hline Fat, \% & 4.17 & 3.55 & 0.20 & 0.02 & 0.001 & 0.17 \\
\hline Fat yield, $\mathrm{kg} / \mathrm{d}$ & 1.60 & 1.42 & 0.11 & 0.22 & 0.25 & 0.34 \\
\hline Protein, \% & 3.22 & 3.28 & 0.07 & 0.47 & 0.78 & 0.48 \\
\hline Lactose yield, kg/d & 1.70 & 1.79 & 0.11 & 0.55 & 0.24 & 0.38 \\
\hline Blood urea nitrogen, $\mathrm{mg} / \mathrm{dL}$ & 16.8 & 14.4 & 1.32 & 0.10 & 0.36 & 0.06 \\
\hline Glucose, $\mathrm{mg} / \mathrm{d}$ & 51.0 & 57.0 & 1.09 & 0.01 & 0.67 & 0.71 \\
\hline $\mathrm{BHBA}, \mathrm{mmol} / \mathrm{L}$ & 0.62 & 0.51 & 0.16 & 0.62 & 0.44 & 0.51 \\
\hline $\mathrm{NEFA}, \mathrm{mmol} / \mathrm{L}$ & 0.36 & 0.38 & 0.03 & 0.75 & 0.74 & 0.32 \\
\hline
\end{tabular}

to concentrations of NEFA and BHBA in plasma and liver.

Results showed average plasma progesterone concentrations was greater in cows fed LIN compared with those fed CON $(1.31 \pm 0.09$ vs. $0.87 \pm 0.09 \mathrm{ng} / \mathrm{mL}$; $P=0.01$ ) at early postpartum. Ruminants fed with protected PUFA were reported to show increased concentrations of progesterone during the luteal phase of the estrous cycle (Walsh et al., 2011). Dirandeh et al. (2013a,b) reported mean serum progesterone concentrations were greater during the luteal phase (d 6 to 16 of cycle, $P<0.03)$ and at the time of insemination in cows fed linseed $(0.80 \pm 0.05 \mathrm{ng} / \mathrm{mL})$ than in cows fed palm oil $(0.15 \pm 0.05 \mathrm{ng} / \mathrm{mL})$. Previous works has suggested that increased progesterone in plasma may not be due to the increased uptake of cholesterol and synthesis by luteal cells, but rather due to the reduction in $\mathrm{P}_{4}$ disappearance from the plasma (Hawkins et al., 1995). Moreover, increased concentration of progesterone has been reported in cows given supplements of CLA (Castañeda-Gutiérrez et al., 2007), which was related to greater circulating IGF-I. Indeed, IGF-I plays a significant role in follicular and luteal development (Perks et al., 1999), promoting proliferation, progesterone production, and increasing LH binding sites of bovine thecal cells. As suggested for fish meal (Mattos et al., 2004), PUFA of the LIN could have reduced the sensitivity of the $\mathrm{CL}$ to $\mathrm{PGF}_{2 \alpha}$, or reduced uterine secretion concentration of $\mathrm{PGF}_{2 \alpha}$ that delayed the completion of functional luteolysis, resulting in a supplementary antiluteolytic effect.

\section{Diameter of Ovulatory Follicle}

The ovulatory follicle (before the first AI) was larger in cows fed LIN compared with those fed CON (15.8 \pm 0.74 vs. $13.6 \pm 0.66 \mathrm{~mm} ; P<0.05)$. Dairy cows fed diets enriched in PUFA had increased dominant follicle diameters compared with the cows fed a diet enriched with MUFA (Bilby et al., 2006), suggesting that PUFA were most effective compared with MUFA. Other studies showed that the size of the dominant follicle was increased in cows that consumed a diet rich in long-chain fatty acids from linseed (Dirandeh et al., 2013a) or soybean oil (Garnsworthy et al., 2008). Cows fed with rolled linseed enriched with ALA ( $56.7 \%$ of total FA) had larger mean diameter of the ovulatory follicle (16.9 vs. $14.1 \mathrm{~mm}$ ) than the cows fed with rolled sunflower seed (0.1\% ALA; Ambrose et al., 2006). These studies clearly indicate the differential effects of FA profile on follicular growth. Cholesterol is the precursor of all steroids and increased substrate availability may increase follicular steroid synthesis (Carroll et al., 1990).

\section{Resumption of Ovarian Activity and Reproductive Performances}

Treatment affected time to postpartum resumption $(P=0.02)$ and was $6.5 \mathrm{~d}$ earlier in the LIN group compared with the CON group (Table 3). Consistent with Juchem et al. (2010) and Silvestre et al. (2011), this study indicates that lipid supplements differing in fatty acid profile influenced the resumption of cyclicity in lactating dairy cows. Prolonged luteal phase and delayed first ovulation were 2 important ovarian dysfunctions that delayed postpartum resumption of cyclicity in high-producing dairy cows (Shrestha et al., 2004). Time to postpartum resumption of ovarian activity was reduced by $7 \mathrm{~d}$ in Holstein cows supplemented with $500 \mathrm{~g} / \mathrm{d}$ of vegetable oil (60\% PUFA) compared with a control group (Marín-Aguilar et al., 2007). Time to first ovulation postpartum was reduced by $8 \mathrm{~d}$ when dairy cows were supplemented with $8 \mathrm{~g} / \mathrm{d}$ of dietary PUFA (trans-10,cis-12 CLA; de Veth et al., 2009). 
Table 3. Effect of linseed on fertility responses of Holstein dairy cows diets based on protected palm oil (CON) or extruded linseed (LIN) from calving until wk 6 postpartum

\begin{tabular}{lccc}
\hline Item & CON & LIN & $P$-value \\
\hline Cystic ovary, \% & 5.6 & 4.4 & 0.03 \\
Day to first service & 66.8 & 60.3 & 0.02 \\
Open days & 126.54 & 124.30 & 0.65 \\
Conception rate at first AI, \% & 48.2 & 47.3 & 0.98 \\
Proportion pregnant, \% & 92.6 & 89.0 & 0.38 \\
\hline
\end{tabular}

These observations demonstrate that PUFA supplementation may influence the resumption of postpartum ovarian cyclicity. Recent studies reported no difference in the proportion of cycling cows at $65 \mathrm{~d}$ after calving when 699 dairy cows were fed $400 \mathrm{~g}$ of fatty acids from either tallow or palm and fish oil containing Ca-PUFA. Subsequently, feeding Ca-PUFA of palm oil or a blend of C18:2n-6 and trans-octadecenoic FA, from $25 \mathrm{~d}$ before to $80 \mathrm{~d}$ after parturition, resulted in similar mean interval to first postpartum ovulation ( $31.3 \mathrm{~d}$; Juchem et al., 2010).

Number of days open, conception rate at first AI, and proportion of pregnant cows were not different among treatments $(P>0.05$, Table 3$)$. This agrees with the results of Dirandeh et al. (2013a), who reported no difference in pregnancy rate at first insemination and conception rate per AI for cows fed soybeans, linseed, or palm oil. However, percentage of pregnancy at d 120 tended $(P=0.08)$ to be higher for cows fed n-3 FA than for those fed palm oil (66.7 vs. $50.91 \%)$. Treatments did not affect interval from calving to pregnancy $(P>$ 0.05). Hutchinson et al. (2012) reported CLA did not affect interval from calving to conception. Results of the present study showed mean ( \pm SEM) days to pregnancy for CON and LIN were, respectively, $103.8 \pm 5.0$ and $97.2 \pm 4.8$ (Figure 1). Similar to our results, Fuentes et al. (2008) reported linseed did not affect interval from calving to pregnancy (median interval from calving to pregnancy was $92 \mathrm{~d}$ for cows fed linseed).

\section{Cystic Follicles}

The incidence of cystic follicles was affected $(P=$ 0.04 ) by the source of fatty acids and cows fed LIN treatment had a lower incidence of ovarian cysts that was consistent with Colazo et al. (2009). Many factors are associated with the development of ovarian follicular cyst in cattle including metritis, retained fetal membrane, and delayed uterine involution (Peter, 2004), reduced LH pulsatility associated with negative energy balance (Ribadu et al., 2000), and hypoinsulinemia (Vanholder et al., 2005). Interestingly glucose concentration was higher in cows fed LIN that could result in higher insulin concentration. We reported linseed feeding after calving improved insulin resistance via affecting somatotropic axis gene expressions and increase insulin concentration (unpublished data). Therefore, hypoinsulinemia may be a predisposing factor to cystic follicle development in the present study. Another mechanism may be related to the higher diameter of ovulatory follicles in LIN treatment that, due to higher estradiol production, can cause LH surge. Growth of ovarian antral follicles beyond 2 to $3 \mathrm{~mm}$ in diameter was largely dependent on FSH, with the final growth and maturation becoming LH dependent. As well as playing a secondary role in follicular responsiveness to FSH, LH is the trigger for ovulation itself. In response to the switch in estrogen-mediated feedback from negative to positive, the LH mid-cycle surge is created. This activates a whole cascade of inflammatory responses in the dominant follicle leading to the breakdown of the follicular boundary wall and the escape of the oocyte with its cumulus oophorus (Campbell et al., 1995). Simões et al. (2012) reported higher follicle diameters increased the ovulation rate and the gene expression of LHR isoforms (M1 + M2 + M3 + M4) in granulosa cells of follicles from Nelore cows.

In conclusion, feeding LIN during early lactation decreased the incidence of cystic follicles that could be related to increased follicle diameter, and influenced the resumption of cyclicity via increased progesterone

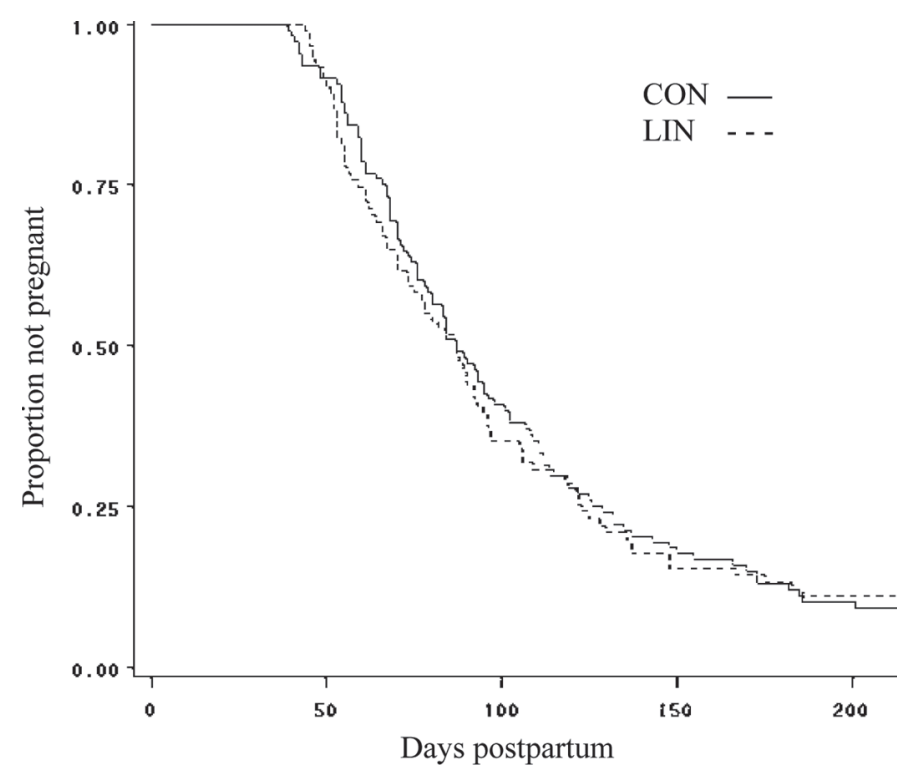

Figure 1. Survival curves for interval from calving to pregnancy in cows fed protected palm oil (CON) or extruded linseed (LIN). Nonpregnant cows at the end of the study were censored. Median interval from calving to pregnancy was 87 and $87 \mathrm{~d}$ for CON and LIN, respectively $(P=0.90)$. Mean $( \pm \mathrm{SEM})$ days to pregnancy for $\mathrm{CON}$ and LIN were, respectively, $103.8 \pm 5.0$ and $97.2 \pm 4.8 \mathrm{~d}$. 
concentrations. Moreover, feeding LIN decreased yield of milk fat in the first $40 \mathrm{~d}$ of lactation.

\section{REFERENCES}

Ambrose, D. J., J. P. Kastelic, R. Corbett, P. A. Pitney, H. V. Petit, J. A. Small, and P. Zalkovic. 2006. Lower pregnancy losses in lactating dairy cows fed a diet enriched in $\alpha$-linolenic acid. J. Dairy Sci. 89:3066-3074.

AOAC. 1990. Official Methods of Analysis. 14th ed. Association of Official Analytical Chemists, Arlington, VA.

AOAC International. 2000. Official Methods of Analysis. 17th ed. AOAC Int., Gaithersburg, MD.

Badiei, A., A. Aliverdilou, H. Amanlou, M. Beheshti, E. Dirandeh, R. Masoumi, F. Moosakhani, and H. V. Petit. 2014. Postpartum responses of dairy cows supplemented with n-3 fatty acids for different durations during the peripartal period. J. Dairy Sci. 97:6391-6399.

Bauman, D. E., and J. M. Griinari. 2001. Regulation and nutritional manipulation of milk fat: Low-fat milk syndrome. Livest. Prod. Sci. $70: 15-29$.

Baumgard, L. H., B. A. Corl, D. A. Dwyer, A. Saebø, and D. E. Bauman. 2000. Identification of the conjugated linoleic acid isomer that inhibits milk fat synthesis. Am. J. Physiol. Regul. Integr. Comp. Physiol. 278:R179-R184.

Bertics, S. J., R. R. Grummer, C. Cadorniga-Valino, and E. E. Stoddard. 1992. Effect of prepartum dry matter intake on liver triglyceride concentration and early lactation. J. Dairy Sci. 75:19141922.

Bilby, T. R., J. Block, B. C. do Amaral, O. Sa Filho, F. T. Silvestre, P. J. Hansen, C. R. Staples, and W. W. Thatcher. 2006. Effects of dietary unsaturated fatty acids on oocyte quality and follicular development in lactating dairy cows in summer. J. Dairy Sci. 89:3891-3903

Caldari-Torres, C., A. L. Lock, C. R. Staples, and L. Badinga. 2011. Performance, metabolic, and endocrine responses of periparturient Holstein cows fed 3 sources of fat. J. Dairy Sci. 94:1500-1510.

Campbell, B. K., R. J. Scaramuzzi, and R. Webb. 1995. Control of antral follicle development and selection in sheep and cattle. J. Reprod. Fertil. Suppl. 49:335-350.

Carroll, D. J., M. J. Jerred, R. R. Grummer, D. K. Combs, R. A. Pierson, and E. R. Hauser. 1990. Effects of fat supplementation and immature alfalfa to concentrate ratio on plasma progesterone, energy balance, and reproductive traits of dairy cattle. J. Dairy Sci. 73:2855-2863.

Castañeda-Gutiérrez, E., B. C. Benefield, M. J. de Veth, N. R. Santos, R. O. Gilbert, W. R. Butler, and D. E. Baumen. 2007. Evaluation of the mechanism of action of conjugated linoleic acid isomers on reproduction in dairy cows. J. Dairy Sci. 90:4253-4264.

Cerri, R. L. A., R. G. S. Bruno, R. C. Chebel, K. N. Galva, H. Rutgliano, S. O. Juchem, W. W. Thatcher, D. Luchini, and J. E. P. Santos. 2004. Effect of fat sources differing in fatty acid profile on fertilization rate and embryo quality in lactating dairy cows. J. Dairy Sci. 87(Suppl. 1):297. (Abstr.)

Chilliard, Y., A. Ferlay, R. M. Mansbridge, and M. Doreau. 2000. Ruminant milk fat plasticity: Nutritional control of saturated, polyunsaturated, trans and conjugated fatty acids. Ann. Zootecnol. 49:181-205.

Chilliard, Y., C. Martin, J. Rouel, and M. Doreau. 2009. Milk fatty acids in dairy cows fed whole crude linseed, extruded linseed, or linseed oil, and their relationship with methane output. J. Dairy Sci. 92:5199-5211.

Colazo, M. G., A. Hayirli, L. Doepel, and D. J. Ambrose. 2009. Reproductive performance of dairy cows is influenced by prepartum feed restriction and dietary fatty acid source. J. Dairy Sci. 92:25622571.

CSIRO. 2007. Nutrient Requirements of Domesticated Ruminants. M. Freer, H. Dove, and J.V. Nolan, ed. CSIRO Publ., Melbourne, Australia; de Veth, M. J., D. E. Bauman, W. Koch, G. E. Mann, A. M. Pfeiffer, and W. R. Butler. 2009. Efficacy of conjugated linoleic acid for improving reproduction: A multistudy analysis in early-lactation dairy cows. J. Dairy Sci. 92:2662-2669.

de Veth, M. J., J. M. Griinari, A. M. Pfeiffer, and D. E. Bauman. 2004. Effect of CLA on milk fat synthesis in dairy cows: Comparison of inhibition by methyl esters and free fatty acids, and relationships among studies. Lipids 39:365-372.

Dirandeh, E. 2014. Starting Ovsynch protocol on day 6 of first postpartum estrous cycle increased fertility in dairy cows by affecting ovarian response during heat stress. Anim. Reprod. Sci. 149:135140.

Dirandeh, E., H. Kohram, and A. Zare Shahneh. 2009. GnRH injection before artificial insemination (AI) alters follicle dynamics in Iranian Holstein cows. Afr. J. Biotechnol. 8:3672-3676.

Dirandeh, E., A. Rezaei Roodbari, and M. G. Colazo. 2014. DoubleOvsynch, compared to Presynch with or without GnRH, improves fertility in heat-stressed lactating dairy cows. Theriogenology http://dx.doi.org/10.1016/j.theriogenology.2014.10.011.

Dirandeh, E., A. Towhidi, Z. Ansari Pirsaraei, F. Adib Hashemi, M. Ganjkhanlou, S. Zeinoaldini, A. Rezaei Roodbari, T. Saberifar, and H. V. Petit. 2013b. Plasma concentrations of PGFM and uterine and ovarian responses in early lactation dairy cows fed omega-3 and omega- 6 fatty acids. Theriogenology 80:131-137.

Dirandeh, E., A. Towhidi, S. Zeinoaldini, M. Ganjkhanlou, Z. Ansari Pirsaraei, and A. Fouladi-Nashta. 2013a. Effects of different polyunsaturated fatty acid supplementations during the postpartum periods of early lactating dairy cows on milk yield, metabolic responses, and reproductive performances. J. Anim. Sci. 91:713-721.

Ferguson, J. D., D. Sklan, W. V. Chalupa, and D. S. Kronfeld. 1990 Effects of hard fats on in vitro and in vivo rumen fermentation, milk production, and reproduction in dairy cows. J. Dairy Sci. 73:2864-2879.

Fourichon, C., H. Seegers, and X. Malher. 2000. Effects of disease on reproduction in the dairy cow. A meta-analysis. Theriogenology 53:1729-1759.

Fuentes, M. C., S. Calsamiglia, C. Sanchez, A. Gonzalez, J. R. Newbold, J. E. P. Santos, L. M. Rodriguez-Alcala, and J. Fontecha. 2008. Effect of extruded linseed on productive and reproductive performance of lactating dairy cows. Livest. Sci. 113:144-154.

Garcia-Bojalil, C. M., C. R. Staples, C. A. Risco, J. D. Savio, and W. W. Thatcher. 1998. Protein degradability and calcium salts of long-chain fatty acids in the diets of lactating dairy cows: Productive responses. J. Dairy Sci. 81:1374-1384.

Garnsworthy, P. C., A. Lock, G. E. Mann, K. D. Sinclair, and R. Webb. 2008. Nutrition, metabolism, and fertility in dairy cows: 1 . Dietary energy source and ovarian. function. J. Dairy Sci. 91:3814-3823.

Garverick, H. A. 1997. Ovarian cysts in dairy cattle. J. Dairy Sci 80:995-1004.

Gonthier, C., A. F. Mustafa, D. R. Ouellet, P. Y. Chouinard, R. Berthiaume, and H. V. Petit. 2005. Feeding micronized and extruded flaxseed to dairy cows: Effects on blood parameters and milk fatty acid composition. J. Dairy Sci. 88:748-756.

Griinari, J. M., D. A. Dwyer, M. A. McGuire, D. E. Bauman, D. L. Palmquist, and K. V. V. Nurmela. 1998. Transoctadecenoic acids and milk fat depression in lactating dairy cows. J. Dairy Sci. 81:1251-1261.

Hawkins, D. E., K. D. Niswender, G. M. Oss, C. L. Moeller, K. G. Odde, H. R. Sawyer, and G. D. Niswender. 1995. An increase in serum lipids increases luteal lipid content and alters the disappearance rate of progesterone in cows. J. Anim. Sci. 73:541-545.

Hutchinson, I. A., A. A. Hennessy, R. J. Dewhurst, A. C. O. Evans, P. Lonergan, and S. T. Butler. 2012. The effect of strategic supplementation with trans-10,cis-12 conjugated linoleic acid on the milk production, estrous cycle characteristics, and reproductive performance of lactating dairy cattle. J. Dairy Sci. 95:2442-2451.

Ingvartsen, K. L., and J. B. Andersen. 2000. Integration of metabolism and intake regulation: A review focusing on periparturient animals. J. Dairy Sci. 83:1573-1597. 
Juchem, S. O., R. L. Cerri, M. Villasenor, K. N. Galvao, R. G. Bruno, H. M. Rutigliano, E. J. DePeters, F. T. Silvestre, W. W. Thatcher, and J. E. P. Santos. 2010. Supplementation with calcium salts of linoleic and trans-octadecenoic acids improves fertility of lactating dairy cows. Reprod. Domest. Anim. 45:55-62.

Marín-Aguilar, M. A., J. C. Tinoco-Magaña, J. Herrera-Camacho, L. G. Sánchez-Gil, V. M. Sánchez-Parra, J. L. Solorio-Rivera, and A. García-Valladares. 2007. Resumption of ovarian activity and level of lipid metabolites in dairy cows supplemented with vegetable oil during the early postpartum. Interciencia 32:180-184. (in Spanish, English abstract).

Martin, C., J. Rouel, J. P. Jouany, M. Doreau, and Y. Chilliard. 2008. Methane output and diet digestibility in response to feeding dairy cows crude linseed, extruded linseed, or linseed oil. J. Anim. Sci. 86:2642-2650.

Mattos, R., C. R. Staples, A. Arteche, M. C. Wiltbank, F. J. Diaz, T. C. Jenkins, and W. W. Thatcher. 2004. The effects of feeding fish oil on uterine secretion of $\mathrm{PGF}_{2 \alpha}$, milk composition, and metabolic status of periparturient Holstein cows. J. Dairy Sci. 87:921-932.

Mattos, R., C. R. Staples, and W. W. Thatcher. 2000. Effects of dietary fatty acids on reproduction in ruminants. Rev. Reprod. $5: 38-45$.

Moallem, U. 2009. The effects of extruded flaxeed supplementation to high-yielding dairy cows on milk production and milk fatty acid composition. Anim. Feed Sci. Technol. 152:232-242.

NRC. 2001. Nutrient Requirements of Dairy Cattle. 7th ed. Natl. Acad. Press, Washington, DC

Perks, C. M., A. R. Peters, and D. C. Wathes. 1999. Follicular and luteal expression of insulin-like growth factors I and II and the type 1 IGF receptor in the bovine ovary. J. Reprod. Fertil. 116:157-165.

Peter, A. T. 2004. An update on cystic ovarian degeneration in cattle Reprod. Domest. Anim. 39:1-7.

Petit, H. V. 2002. Digestion, milk production, milk composition and blood composition of dairy cows fed whole flaxeed. J. Dairy Sci. 85:1482-1490.

Petit, H. V., and C. Benchaar. 2007. Milk production, milk composition, blood composition, and conception rate of transition dairy cows fed different profiles of fatty acids. Can. J. Anim. Sci. $87: 591-600$

Ribadu, A. Y., K. Nakada, M. Moriyoshi, W. C. Zhang, Y. Tanaka, and T. Nakao. 2000. The role of LH pulse frequency in ACTH induced ovarian follicular cyst in heifers. Anim. Reprod. Sci. 64:21-31.

Roberts, C. J., I. M. Reid, G. J. Rowlands, and A. Patterson. 1981. A fat mobilization syndrome in dairy cows in early lactation. Vet. Rec. 108:7-9.
Santos, J. E., R. S. Bisinotto, E. S. Ribeiro, F. S. Lima, L. F. Greco, C. R. Staples, and W. W. Thatcher. 2010. Applying nutrition and physiology to improve reproduction in dairy cattle. Soc. Reprod. Fertil. Suppl. 67:387-403

Santos, J. E., S. O. Juchem, R. L. Cerri, K. N. Galvao, R. C. Chebel, W. W. Thatcher, C. S. Dei, and C. R. Bilby. 2004. Effect of bST and reproductive management on reproductive performance of Holstein dairy cows. J. Dairy Sci. 87:868-881.

Santos, J. E. P., T. T. Bilby, W. W. Thatcher, C. R. Staples, and F. T. Silvestre. 2008. Long chain fatty acids of diet as factors influencing reproduction in cattle. Reprod. Domest. Anim. 43:23-30.

Schingoethe, D. J. 1996. Balancing the amino acid needs of the dairy cow. J. Anim. Feed Sci. Technol. 60:153-160.

Shrestha, H. K., T. Nakao, T. Higaki, T. Suzuki, and M. Akita. 2004. Resumption of postpartum ovarian cyclicity in high-producing Holstein cows. Theriogenology 61:637-649.

Silvestre, F. T., T. S. M. Carvalho, N. Francisco, J. E. P. Santos, C. R. Staples, T. C. Jenkins, and W. W. Thatcher. 2011. Effects of differential supplementation of fatty acids during the peripartum and breeding periods of Holstein cows: I. Uterine and metabolic responses, reproduction, and lactation. J. Dairy Sci. 94:189-204.

Simões, R. A., R. A. Satrapa, F. S. Rosa, M. Piagentini, A. C. S Castilho, R. L. Ereno, L. A. Trinca, M. F. G. Nogueira, J. Buratini Jre, and C. M. Barros. 2012. Ovulation rate and its relationship with follicle diameter and gene expression of the LH receptor (LHR) in Nelore cows. Theriogenology 77:139-147.

Van Soest, P. J. J. B. Robertson, and B. A. Lewis. 1991. Methods for dietary fiber, neutral detergent fiber and non-starch polysaccharides in relation to animal nutrition. J. Dairy Sci. 74:3583-3597.

Vanholder, T., J. L. Leroy, J. Dewulf, L. Duchateau, M. Coryn, A. de Kruif, and G. Opsomer. 2005. Hormonal and metabolic profiles of high-yielding dairy cows prior to ovarian cyst formation or first ovulation post partum. Reprod. Domest. Anim. 40:460-467.

Walsh, S. W., E. J. Williams, and A. C. Evans. 2011. A review of the causes of poor fertility in high milk producing dairy cows. Anim. Reprod. Sci. 123:127-138.

Ward, A. T., K. M. Wittenberg, and R. Przybylski. 2002. Bovine milk fatty acid profiles produced by feeding diets containing solin, flax and canola. J. Dairy Sci. 85:1191-1196.

Zachut, M., A. Arieli, H. Lehrer, L. Livshitz, S. Yakoby, and U. Moallem. 2010. Effects of increased supplementation of omega-3 fatty acids to transition dairy cows on performance and fatty acid profile in plasma, adipose tissue, and milk fat. J. Dairy Sci. 93:58775889 . 